\title{
Finding Courage in the Unknown: Transformative Inquiry as Indigenist Inquiry
}

\author{
Michele Tanaka
}

University of Victoria

\begin{abstract}
Educators often wonder how to respond purposefully to vexing issues such as ecological sustainability, social justice and holistic health and wellness. The search for useful ways of proceeding can be addressed through engagement in the process of Transformative Inquiry (TI), a mode of inquiry for educators that resonates with indigenous views and ways of being. At its heart, the approach seeks to support preservice teachers in their personal journeys towards decolonizing and indigenizing. Ultimately, these efforts ripple out to affect their future students and the institutions in which they learn, teach, and, hopefully, inquire. Weaving poetry, written from my own experience on becoming indigenist, with the work of scholars such as Manulani Meyer, Lorna Williams, Marie Battiste, Shawn Wilson, and Gregory Cajete, I highlight salient aspects of TI that can be particularly useful in changing the trajectory of both education and educational research: welcoming spirit, deep and generous listening, connecting to place, and finding courage in the unknown.
\end{abstract}

Keywords: Transformative Inquiry; indigenizing education; decolonizing research; teacher education; educational research

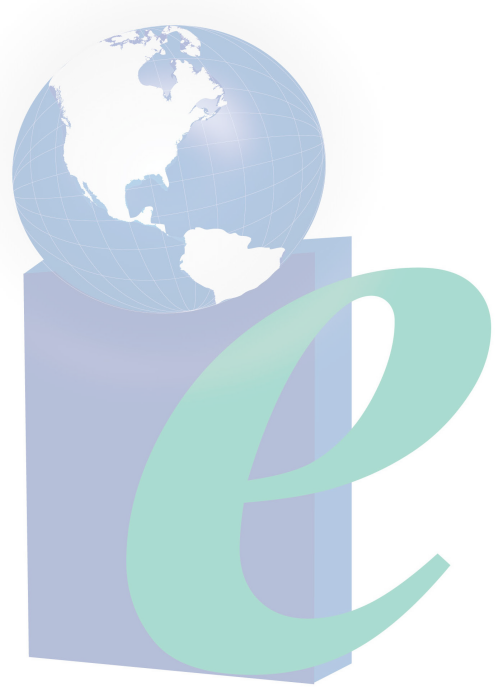




\title{
Finding Courage in the Unknown: Transformative Inquiry as Indigenist Inquiry
}

\begin{abstract}
We will wake up or stay asleep with regard to how best to research/understand, and thus educate our children in this time of homogenization, fear and amoral intentions... It's time. It's time because the world needs our clarity, and we need our own. (Manulani Meyer, 2003, p. 249)
\end{abstract}

We live in an era where age-old patterns and rhythms of life on Earth are changing significantly; many of us feel a deep sense of urgency in our hearts, minds, souls, and bodies as this increasingly accelerated process unfolds. Educators often wonder how to respond purposefully to vexing issues such as ecological sustainability, social justice, and holistic health and wellness. Our trajectory is likely not maintainable; in many and varied ways, we are deeply wounding the planet, each other, and our very souls. How do educators and educational researchers best proceed in this turbulent complex terrain to help all learners fulfill their potential? How do we shift unbeneficial patterns of consumption, exclusion, and insatiability? Educators and educational researchers hold a great deal of power and possibility; we are well positioned to influence the next generation of learners and in particular, how they interact with the burning questions of the world. But what kind of educator does the world need today? Which modes of inquiry are best suited to bring clarity to educational challenges?

Indigenous modes of learning, teaching, and inquiry bring forward ancient knowledges that have long been integral to sustainable practices. Transformative Inquiry (TI) is a mode of inquiry that resonates with and draws from indigenous ${ }^{1}$ ways of learning and teaching (Tanaka 2014; Stanger, Tanaka, Tse, \& Starr, 2013). At its heart, the TI approach seeks to support preservice (student) teachers in their personal journeys towards decolonizing and indigenizing as they learn to be professional educators. Ultimately, these efforts affect their future students and the institutions in which they teach.

In this article, I bring forward key aspects of TI that specifically add to the conversation around indigenizing learning, teaching, and researching: welcoming spirit, deep and generous listening, connecting to place, and finding courage in unknowing. To further illuminate what the process of indigenization might look like for someone entrenched in Western perspectives, I weave in poetry that describes my own experience of becoming more indigenist. The tensions represented in this poetry will be drawn on to further clarify what is unsettled in the process of indigenizing and what are some of the difficulties of listening outside of habitual ways of knowing.

\section{Locating Myself}

By many definitions I am not Indigenous, yet I am becoming indigenist. I feel a direct call to engage in indigenous modes of inquiry. Because of conflicts inherent to this path, the first time I read Shawn Wilson (2007) on indigenist research paradigms, I let out a sigh of relief:

It is the philosophy behind our search for knowledge that makes this new knowledge a part of us, part of who and what we are. And it is then the 
choice to follow this paradigm, philosophy, or world view that makes research Indigenist, not the ethnic or racial identity of the researcher. (p. 194)

My heart flew yet again when Manulani Meyer (2008) shared her "practice of Aloha, the intelligence of compassion, empathy and care” (p. 221).

Knowledge that does not heal, bring together, challenge, surprise, encourage, or expand our awareness is not part of the consciousness this world needs now. This is the function we as indigenous people posit. And the great clarity that I have been waiting to express through the beautiful mind of our beloved kupuna healer, Halemakua: We are all indigenous. (pp. 221-222)

Both of these writings resonated with beliefs I held deep in my heart and began to shift me towards being more consciously indigenist. Now, as a researcher and teacher educator working with issues of culture and ways of understanding, I make deliberate choices to follow an indigenist paradigm, to practice the intelligence of compassion, empathy, and care. As I delve further into the relational connecting awareness that indigenous scholars advise, relationships with my students are strengthened and learning becomes more relevant and alive.

What follows is a small poetic invocation describing some of my own personal tensions that are an undercurrent to the work of decolonizing myself. I see this as a process of creating an awareness of who I am that helps me better walk my talk with my students (see also Tanaka, Nicholson \& Farish, 2012; Tanaka \& Tse, forthcoming). For me, writing poetry takes me out of my head and into my heart; reductionist thinking is left behind as emotional knowing takes over. It is often a relief to enter into these spaces away from typical academic intellectualism. I hope you, as the reader, might feel the same. Before and after reading each poem, I invite you to take a moment to breath and simply be.

\section{Leaving Earth Awareness}

In my blood

i hold

these stories

Scotch

Irish

German 


\section{Norwegian}

English

French Creole

\section{Cajun}

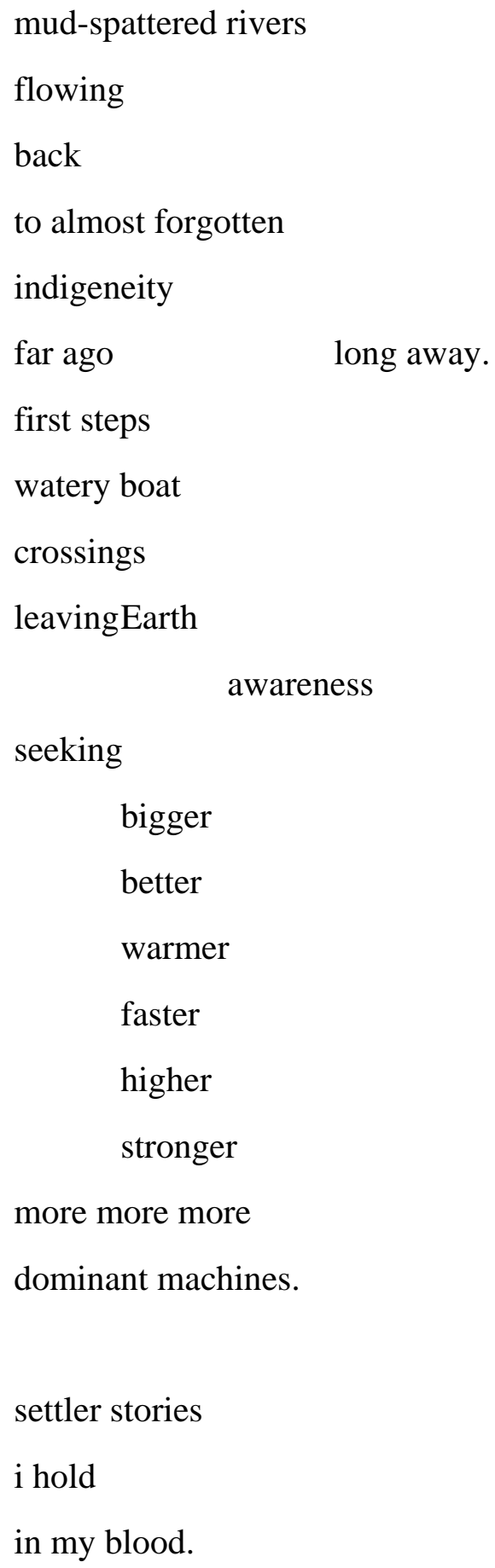


and

that's not all of me

This poem helps me to remember that locating myself means going back into my familial history. I am who I am because of the actions of my ancestors. In my case, as with most of us, this is a complex set of interwoven stories that include elements of privilege, loss, adventure, love, power, and more. Upon closer examination, I begin to appreciate how these often-conflicting emotions and elements have played out through the generations.

\section{The Emergence of Transformative Inquiry}

In 2006, I was welcomed in as a researcher to study a teacher education experience at the University of Victoria in British Columbia, Canada. The course, Earth Fibres, Weaving Stories: Learning and Teaching in an Indigenous World, was a successful decolonizing project that immersed preservice teachers into indigenous ways of learning and teaching through working with various earth fibres (Tanaka, forthcoming). Designed and implemented by Lorna Williams, the course was as an act of courageous and gentle resistance to the ingrained patterns of Eurocentric education. Wisdom keepers from several communities created space, time, and intention for ancient and evolving indigenous pedagogies to emerge and thrive (Williams \& Tanaka, 2007). TI has emerged in resonance with the teachings in this course.

The ways of being, doing and knowing in the Earth Fibres course were very different than what is typically privileged in Western education systems schools and schooling. Educators have too often been trained to favor reductionism and separating logic. Consequently, we can miss the relational connecting awareness that complicated problems require. One example of this would be the tendency to separate learners from teachers from researchers. In TI, the lines between these roles are consciously blurred; participants become active learner teacher researchers. This sensibility underlies my writing here. As I engage in this publication process I am learning from the collaborative review process, teaching by sharing my experience, and researching my own beliefs and the connections they have with others through both the prose and poetic writing processes. By weaving together relational indigenous knowledges and analytical dominant knowledges, we can better identify and address our collective needs (Battiste \& Henderson, 2009).

Because of the Earth Fibres course, my personal ways of being in the world, including my research and my work with preservice teachers, were forever changed. My tendency towards reductionist logic began to migrate towards relational accountability (Wilson, 2008). I moved increasingly towards becoming an indigenist (Wilson, 2007), finding deep resonance and direction in indigenous worldviews. I continue to walk with the teachings, further developing TI in my work as an educator of preservice teachers preparing to be both elementary and secondary teachers. TI has its roots in the Earth Fibres course experience; the knowledges brought forward by the wisdom keepers there, ripple out through me in this context today. 
Drawing from the teachings of the earth fibre elders, the TI approach was developed alongside a community of teacher educators and preservice teachers who wanted to address the demands of teaching in the complexity of today's classrooms. TI is embedded as a required course in the final months of our elementary teacher education program and is also part of an elective Indigenous Institute within the secondary program. In both contexts, students begin the course by connecting with their "path with heart" (Chambers, 2004) as they each unearth salient issues about which they care about both personally and professionally. Typically they choose topics relevant to the context of their own teaching practice and, therefore, topics that also matter to other educators. These include a vast array of issues such as teacher identity, honesty in the classroom, assessment and integrity, cultural expectations, learning with the arts, creating safe space, listening to student voice, and so forth. These topics are explored through a personal, relational and emergent combination of self-study, journaling, artistic expression, peer interaction, community engagement, and one-on-one mentoring with instructors.

Rather than look for prescriptive solutions to these often burning, pervasive issues, students are encouraged to seek understanding through exploration of open-ended and unbounded questions (Henderson, 1992). This typically takes them on a meandering path, rather than one that is linear and concise. Exploring cul-de-sacs and unanticipated turns, students often discover what really matters for them as educators. For example, Liz, a student, began her inquiry with the topic of no-touch policies in schools and imagined herself engaging in a typical literature review. Her instructor suggested expanding her questions first, and this shifted her trajectory. Liz began to consider her deep concerns "for the poor who have little access to education; for the earth; for boys and girls and whether we educate them correctly; for genuine happiness and purpose; for imagination and wonder" (Tanaka et al., 2014, p. 217). This seemingly scattered exploration was uncomfortable for someone who was, in her words, "driven by the rewards of grades" (p. 216). She stayed with the TI process, however, and through an expressive painting, eventually found herself embracing an unexpectedly rich new topic.

What was once the scenery of the outside world, the 'them', the 'other', 'the system' rolling by as I moved along, suddenly became my own interior scenery; my past, my childhood, the world inside of me. It was no longer possible to remove myself from my inquiry... A transformation was occurring: I went from longing for a more traditional assignment to lessen the niggling questions and mental blocks, to embracing the questions as they materialized, and finally to splashing around in them like a playful child on a sunlit summer afternoon....I realized that the surfacing of the [no-touch] question in my mind was a beacon leading me to acknowledge that the reason I simultaneously cared and was distressed by the policy was because I had been a lonely, neglected child myself-simple as that. (Tanaka et al., 2014, p. 218)

Through her meandering, Liz’s topic transformed from no-touch policy to deeper questions about her own experience and how these play out in her teaching.

Another student, Vanessa, was asked to begin the TI process by identifying what keeps her up at night: 
A few ideas churned within me, bursting like sparks from a fire. I constructed a bullet-point list of academic topics: brain-gym, brain-based learning, and minorities in the classroom. I hesitated. What do I really care about? A word rattled around in my heart, like a fly struggling to be released from a web. With a thudding pulse I printed the anxiety-laden word at the bottom of my list: biracial. I was surprised by the naked emotion the word evoked in me. I went home and for the first time in a long time, I wrote a poem, which began:

Does a soul have a colour?

Unbound by the pulse of individuality,

The bones of family,

The muscles of culture. (Tanaka et al., 2014, p. 209)

At her first mentoring session, Vanessa was almost apologetic about her topic, "What does it mean to be a racialized teacher teaching in predominately white spaces" (Tanaka et al., 2014, p. 209). She worried it would be too personal to bring up in the course. Her instructor reassured her that if she stayed with a topic she really cared about, she would have the option of sharing only what she wanted when the time came. Vanessa trusted poetry as being a valid mode of inquiry and eventually wrote a poem entitled "Diaspora Fruit.”

[In this poem I wrestled] with how to collapse dichotomies into a whole. I had always felt like I needed to be either Chinese or White. But what does that really mean? ...Later...I struggled to describe my realization that the fruit, like myself, was more than a fusion of disparate parts, but a new entity. I came to realize that identity is not so black and white. (Tanaka et al., 2014, p. 211)

Through persistence, poetry and passion, the TI process supported Vanessa in looking deeply at the crux of her issue so that she could follow her path with heart as a learner teacher researcher.

In TI, three overarching questions suggested by Gregory Cajete (2009) are used as guiding stars, important indicators for all learner teacher researchers: How are we going to deal with the environmental crisis as it is today? How are we going to learn to live with each other? And, how do we take care of our own souls? During a 4-year study funded by the Social Sciences and Research Council of Canada, I tried to capture a sense of how people change on deep dispositional levels through the TI process (please download our free interactive iBook text at http://www.transformativeinquiry.ca/downloads/).

\section{Reframing Research to Include Our Deep Need}

We live in an era of fractured cosmologies where consumption and power often distort and sap viable solutions, often leaving unmet, our basic human needs such as ecological sustainability, social justice and holistic health and wellness. Manulani Meyer (2003) suggests we start by remembering "research is not simply about asking 'burning questions' we want resolved, but rather, we are answering a call to be of use” (p. 249) in 
our communities. As an educational researcher, I attend carefully to how I might be of use. In particular, I try to learn how to do the personal work of decolonizing and indigenizing so that it can ripple out into the larger world. To re-pattern ways of being, knowing and doing on fundamental levels (both personally and institutionally). To attend carefully to connections to place, how I am in relation to others, and who I am in my innermost soul. To know what I care about, why I care, and how to articulate my concerns to others - this is especially true when what I care about is marginalized and/or vulnerable. To learn how to work together more generously, and how to distinguish between what I think I need, what I actually need, and how my consumption affects the community and all sentient being on Earth. And, perhaps most importantly, I try to be aware of what gets in the way of these intentions; here is where the deepest work of transformation resides.

Marie Battiste and Sa'ke'j Henderson (2009) point out that indigenous theoretical and methodological paradigms can create shared capacity when used in combination with western ways of knowing. By naturalizing indigenous knowledges into education, a "trans-systemic synthesis" of pedagogies is created (p. 16). This "difficult and arduous journey," (p. 16) this weaving together of seemingly disparate modes, is that with which we must embark if we are to meet our needs and be of use. Battiste and Henderson (2009) further describe how Indigenous knowledge "allows peoples to confront despair, resignations, intolerance, racism, injustice, and power with momentum, conflict, spirit and heart” (p. 9). TI is one mode of inquiry that supports time and space for the weaving of western and indigenous ways.

Inherent to this project of weaving is the danger of cultural appropriation. I am not Indigenous; yet I find myself in a place where indigenous knowledges often seem the most beneficial. It is difficult to know how to proceed when I'm not sure if I belong enough to use the knowledge I have come to know. Of course, insider/outsider categories are not easy to determine and are not always useful (Kovach, Carriere, Barrett, Montgomery, \& Gillies, 2013). Again, Shawn Wilson (2008) helps me to proceed.

If knowledge is formed in a relationship, it can't be owned. I guess you could ask, would you own the knowledge or would it own you? It becomes cultural appropriation when someone comes and uses that knowledge out of its context, out of the special relationships that went into forming it. You have to build a relationship with an idea or with knowledge, just like you have to with anything or anyone else. (p. 114)

For me, my work towards indigeneity is in part, about recognizing what owns me and having the courage to follow this knowledge. I do this while respectfully nurturing relationships with community elders, indigenous scholars, the land that sustains me, and all sentient beings I encounter-be they spiders in the kitchen or deer in the yard. Of course, I make mistakes in this; it is a process of becoming. TI at its heart is indigenizing work.

\section{the knowledge owns me}


tears spring

to my eyes

oh! not here!

this is a place

of Intellect.

Posturing.

A certain kind of Knowing.

still,

you

open me.

my heart

cannot turn away.

later,

mouse paused

over unopened files

a voice cries:

too hard!

write something else!

this is

too heavy,

too

unsettling.

still,

I open

the file.

because

this work 


\author{
is really all i know \\ because \\ there's no \\ turning back \\ because \\ the knowledge \\ owns me \\ because \\ my heart cannot \\ turn away \\ tears direct \\ my inner mouse \\ opening \\ into \\ knowledges \\ beyond \\ who I thought i was \\ and that's \\ not all of me
}

This poem describes some of my experience after I heard Manulani Meyer speak a number of years ago at an academic conference. Her inclusion of spirit within the academy touched my deep need and I was overcome with emotion. The same thing happened when I heard Gregory Cajete speak about his three simple questions for educators. Both times, I felt worried and embarrassed to be moved to tears at a conference, but most of all I felt relieved. Here were academics speaking sense to me-at the time I so needed voices of reason, places for which to aim. Their courage to speak their truth gives my little mouse heart courage to do the same.

\title{
Welcoming Spirit, Listening, Place, and Courage
}

During the Earth Fibres course experience and a prior carving course I had taken, I began 
to learn some of the key indigenous principles Lorna Williams brings forward from her own Lil'wat traditions. These include: Celhcelh, developing a sense of responsibility for personal learning within the context of a learning community; Emhaka7, encouraging everyone's best work at whatever task is before us; Kat'il'a, finding stillness amidst our busy need to know; Kamúcwkalha, the acknowledgement of group attunement and the emergence of common group purpose; and Cwelelep, the discomfort and value of being in a place of dissonance and uncertainty (Sanford, Williams, Hopper, \& McGregor, 2012; Tanaka et al., 2007; Williams \& Tanaka, 2007). These principles were embedded into the Earth Fibres course by the very fact that they were deeply integral to her being, doing, and knowing; Lorna acted from her ancestral beliefs. As the courses proceeded, she spoke about these principles outwardly and I have fond memories of sitting near the pole we were carving as she shared her teachings.

I took Lorna's cultural teachings to heart and have brought them forward into the development of the TI process. Here I highlight four aspects of TI that are particularly resonate with Lorna's principles and are also supportive of weaving together indigenous and Western ways of being: welcoming spirit, deep and generous listening, connecting to place, and finding courage in unknowing. These aspects are not listed in a particular order because they are interrelated, non-prescriptive, and non-hierarchical in nature. TI works at developing new patterns of doing, being, and knowing at deep dispositional levels; its purpose is to change our entrenched beliefs, values and attitudes. This is an iterative and continuous process. Reading on, keep in mind that TI is applicable beyond the realm of teacher education; begin to imagine how facets of TI could unfold in other locations.

\section{Welcoming Spirit}

Manulani Meyer (2003, 2008) describes knowledge as an ever-expanding experience requiring attention on three levels of perception: gross (objective, body, physical), subtle (subjective, mind, rational) and causal (transcendental, spirit, contemplation). Awareness of and engagement in these three levels results in a "triangulation of meaning," propelling us forward in our evolutionary journey. People engaged in Western modes of inquiry tend to utilize and perceive through either the gross (e.g., collecting data, numbers, and observations) or the subtle (e.g., thinking about or analyzing these data, numbers, and observations). Limiting attention to the causal, results in an incomplete triangulation of meaning, a partial understanding of experience.

Essentially, the usefulness of gross and subtle modes of perception can be fueled by attention to the causal; triangulation of meaning occurs through holistic awareness and engagement. As described by Meyer (2003), our causal nature has to do with "spirit, the deep animating principle found in matter" (p. 253). It is a place where "dualities merge and knowledge becomes less a thing than an event, a stirring, a final reaching in” (p. 253). Our causal roots animate how we inquire, creating contexts where "causal knowledge breathes and deepens our connection to all things. All people. All ideas" (p. 254). Yet, despite unfolding efforts to indigenize education and research, those of us trained through Western education systems often do not seem to understand the important role of causal knowledges and/or to have the courage to engage them. The consuming quest of tenure, pressure to adhere to departmental/university standards, and fear of deviating from academic norms all contribute to this inertia. But excluded causal 
knowledges from our learning teaching researching omits an important way of knowing that can ultimately address our deepest needs more holistically and therefore more effectively.

Consider what editors of the Canadian Journal of Native Education (Restoule, Archibald, Lester-Smith, Parent, \& Smillie, 2010) write: "When we approach our research in a good way, with good hearts and good minds, spirit manifests to make things happen...Connection to spirit is lived daily and is inseparable from research work" (p. 3). We are holistic beings, yet we often try to solve problems through a division of heart and mind. If spirit is "a mysterious energy that pervades the universe and gives life its essence, that animating force which joins all living things together" (Restoule et al. 2010, p. 1), we do well to bring this enlivening force consciously into various aspects of learning, teaching, and research.

In addition, a focus on each person's individual core needs and aspirations (Battiste \& Henderson, 2009) supports an emergence and strengthening of their learning spirit (Battiste, 2009). This resonates with the notion of vocation or calling, experienced as "the place where your deep gladness and the world's deep hunger meet" (Buechner, 1993, pp. 118-119). Battiste and Henderson (2009) posit,

When [Indigenous knowledge] is naturalized in educational programs, the learning spirit is nurtured and animated. Individually and collectively, Aboriginal people are able to decolonize themselves, their communities, and institutions, leading to transformation and change; and everybody benefits. Indeed naturalizing [Indigenous Knowledge] creates potential for Aboriginal and non-Aboriginal learners in trans-systemic ways that [Eurocentric knowledge] alone cannot do. (p. 13)

Nurturing the learning spirit leads to learner teacher researcher autonomy and the Lil'wat concepts of Celhcelh, developing a sense of responsibility for personal learning, and A7xekcal, valuing our own expertise and considering how it spreads beyond our individual selves to help the community at large. The causal, transcendental and spiritual can work with the gross and subtle to create a certain atmosphere of care.

The way we come to know matters greatly and perhaps more so than what it is we eventually come to know. Emphasizing the process, the journey, the path, the way... speaks to the necessity of nurturing a spirit of humility when we undertake our research. (Restoule et al., 2010, p. 4)

It is important to practice new ways of attending consciously and with regularity. For me, poetry is a vehicle for this awareness. As I attend to my spiritual nature, I become more sensitive to my own complexity and that of the people with whom I engage in research. The tensions and potentials of our heritage, our collective stories, are brought to fuller awareness. This atmosphere of care engages Emhaka7, encouraging each of us to do the best we can at the task at hand.

breathing 


\section{in \\ breathing \\ out \\ emptiness is \\ form \\ form}

is emptiness

\section{Deep and Generous Listening}

Stories are at the heart of all learning and teaching (Cajete, 1994) as well as indigenous research (Archibald, 2008; Iseke, 2013). One important TI saying is: speak to be revealed, listen to be changed (Altman, 2012). As we learn, teach, and research, we practice sharing stories with honesty. We listen in generous ways (Thayer-Bacon, 2003), beyond what we believe to be possible or true. This can lead to subtle shifts in patterned ways of being, doing and knowing. As Kovach describes, "Indigenous approaches to research for many may not simply be about research-they are more holistic, experiential, and spiritual than that. They are something more. That "something more" is found in our stories" (Kovach et al., 2013, pp. 505-506). That we listen, and how we listen, is paramount.

In TI we practice how to listen beyond what it is we think we know about another person, beyond what it is we want to say when they are done talking. Eurocentric habits of efficiency (Stein, 2002), being organized and goal oriented at the expense of relaxed awareness, listening and consideration, are strong in education and educational research. We can come to recognize that "we are not 'dumbing down' methodology when we wish to sit and listen-for years” (Meyer, 2003, p. 253). This type of quiet attention resonates with Lorna Williams' principle of Kat'il'a, the act of becoming still and slowing down, despite an ingrained and urgent need to know and a desire for busyness.

In the context of the TI course, listening well leads us to become a community of learner teacher researchers that are relationally accountable. We base our interactions in respect, reciprocity, and responsibility. All participants are recognized as knowledge holders and everyone is expected to seek conversations about the topics we care about beyond the notion of academic expertise. We make conscious efforts to extend this into community by talking with children, teachers, parents, elders, and other knowledge 
holders. Battiste and Henderson (2009) suggest that such an orientation builds "a successful learning continuum and healthy, resilient communities” (p. 11). The Lil'wat principle that takes hold here is Kamúcwkalha, the energy current indicating the emergence of a communal sense of purpose.

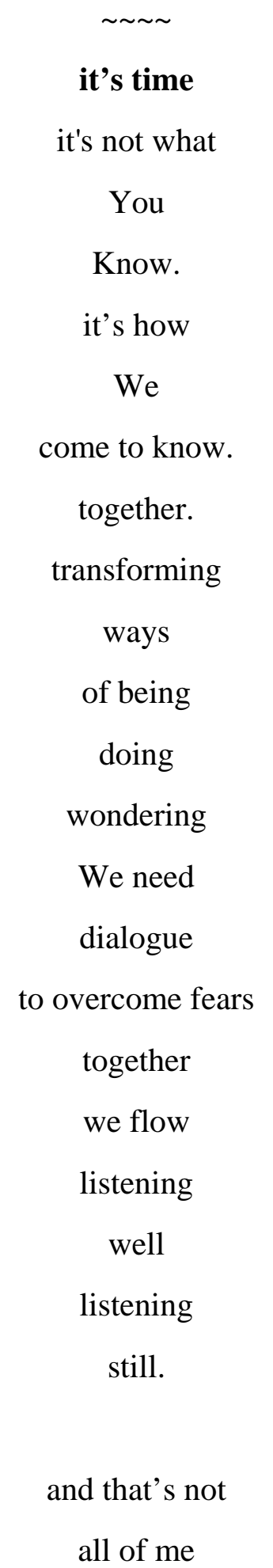




\section{Connecting to Place}

Linda Tuhiwai Smith (2012) reminds us that indigenous research is a "humble and humbling activity" (p. 5). The English word "humble" comes from the Latin humus, of the earth (Oxford English Dictionary). What does being in nature tell us about our research approach? Our questions? How does the focus of our research affect the wellness of the planet? What would change if everyone involved in research brought his or her questions right out onto the land? Cynthia Chambers (2008) thinks carefully about the importance of developing a curriculum of place in decolonizing work. She describes how on the land, there is a different sense of time, an embodiment of skill, an education of attention, and a wayfinding that become possible. She writes, "It is where we are that matters. By learning to do what is appropriate in this place, and doing it together, perhaps we can find the common ground necessary to survive” (Chambers, 2008, p. 125). The TI course meets outside when possible and I encourage students go outside frequently to see how their topics of inquiry might connect to place. I suggest they listen to what Earth has to say to them.

Place is also about a deep location of self. A common refrain in teacher education is that we teach who we are (Palmer, 1998). I think we research who we are as well; our deepest beliefs come out in our questions and how we follow them. If this is true, it is useful to know our selves - our every action is influenced by our unconscious being, doing and knowing. Processes of deepening awareness can lead to a decolonizing of self, a "critical consciousness awakening" that must be made visible (Henhawk, 2013, p. 511). It is continual and difficult; as Henhawk (2013) shares, "I've constantly had to reflect upon whether my very presence in the academy maintains my complicity with it" (p. 511). Further, he asks, "How does one resist and turn their back on things they've believed their whole lives?" (p. 513). Disrupting long held beliefs can lead "to epistemological dizziness and nausea” (McIntosh, 1998). No wonder we would rather ignore the call. When we do take the leap, we have to be careful that this is not merely a "settler move towards innocence" (Tuck \& Yang, 2012), but a genuine honest look at the epistemological ground on which we stand.

Restoule et al. (2010) point out that this locating of self should be holistic and grounded in spirituality.

One way in which Indigenous research is distinct from other research approaches is that, in locating self, we identify ourselves not only by our social markers (such as gender, race, class, etc.) but we also locate ourselves in relation to spirit (p. 2).

This is a far cry from the Eurocentric notion that knowledge can somehow be separated from the realms of spirit. And spirit is deeply tied to place.

\section{Re-settling}




\author{
Venturing up \\ mountain path \\ quiet \\ rare \\ stillness \\ fog engulfed \\ day. \\ alone with \\ my thoughts \\ feeling further grounded \\ with each step \\ energized \\ in ways \\ that don't happen \\ any other place
}

Twelve years

here

i am just beginning

to know this land.

Climbing Mt. Doug

reclaimed Pkols

crisp horizon

narrow line

of blue,

clearing sky

up island.

Here,

heavy clouds 


\author{
gentle wind. \\ winter torrents \\ faded memory. \\ I feel my roots \\ extending \\ once again. \\ From you \\ i learn \\ to stand \\ in my truth \\ quiet rain \\ falling \\ all around \\ I am beginning \\ to not find it \\ strange \\ that seagulls \\ soar \\ overhead. \\ and that's \\ not all \\ of me
}

\title{
Finding Courage in Unknowing
}

Inherent in a deep locating of self is the possibility of realizing and accepting the limits of our patterned ways of being, doing, and knowing. Decolonizing is an unsettling process, 
it "is not an 'and'. It is an elsewhere” (Tuck \& Yang, 2012, p. 36). As Kumashiro (2008) writes, educators

need certain knowledge, but also need to know the limits of their knowledge. They need certain skills, but also need the skill of troubling whatever they do. They need certain dispositions, but also need to be disposed to uncomfortable changes in these very dispositions. (p. 239)

This brings us to the Lil'wat concept of Cwelelep, the sense of knowing that we don't know, while engaging a sense of openness to the possibilities of new learning.

It would be easier if there were prescriptive steps as to how to decolonize or take an indigenous approach, but this is impossible given our complexity as individuals and in relationship. Efforts of indigenizing learning teaching researching require partnerships with learners, teachers, researchers, community members, and Earth. In a landscape that can feel unsympathetic and sometimes hostile towards change, my timid mouse self has to find courage to find ways of carrying forward the teachings that I know in my heart to be true.

I agree with Manulani Meyer (2008) who says, "Power, hegemony, colonization, racism, and oppression are the labels on [our] acts of denial. I now see these as unawareness" (p. 218). Too often, as learner teachers researchers, we particularly and specifically ignore these things. There is much work to be done here. We must continue to locate ourselves and try to remain conscious whenever possible. As Lata Mani (2009) writes,

negativity frequently secures itself by means of fear. Fear brings lack of clarity [which] leads to despair and disempowerment... Accepting what we cannot do and opening further to what we can do maximizes our readiness to be present for what we must do. (p. 139)

How do we open further to what we can do as researchers? For me it is a process of looking fear in the face, to be comfortable (enough) in my unknowing, to move with courage and attend with an atmosphere of care. To actively evoke relationally accountable communities where each person has support to know themselves more fully, and to witness the layers of patterned ways of being, doing, and knowing. I watch for separating logic, try to see the relationships, and visit Earth for guidance on my way forward. I try to find and follow my own learning spirit and nurture the spirit of those around me. I am learning to tell my story with truth and clarity and above all, listen to be changed. 


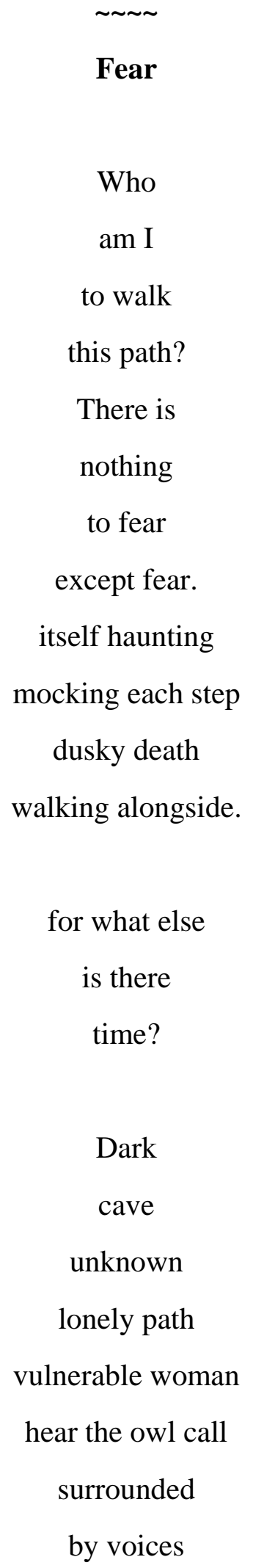


unheard

by

others.

Each

purposeful

step

buries

fear

fuck

fear

and that's

not all

of me

\section{Closing Thoughts}

I lift up my hands in thanks to the land from which all knowledge extends, the elders who have passed this knowledge forward for generations, and my awakening soul that propels me to continue this work around ecological sustainability, social justice, and holistic health and wellness. Personal and institutional tendencies, privileges, politics, and apathy hinder these efforts, and yet change is what we collectively yearn for, and is in fact, inevitable. Increasingly, this work is all I know to do. I invite all educators and academics to consider actively "initiating a new story” (Lewis, Montgomery, Campbell, Ritenburg, \& Diversi, 2013). Towards this aim, we can draw purposefully from indigenous knowledges, part of the "collective genius of humanity" (Battiste \& Henderson, 2009, p. 13).

Over the years, I have now walked alongside hundreds of students engaged in the TI process. I have noticed how careful inner work is essential to creating personal change and that personal change affects other people and, thus, the institutions we create. Often this means becoming aware of what gets in the way of our intentions and being honest about our faults and feelings. As we attend to who we are, we are transformed and our actions are altered as well.

In your particular context, how do you imagine the possibilities of decolonizing and indigenizing - what might this look like, feel like, and taste like to you? Given the 
needs that surround you, how might you be of use? Join and initiate efforts to disrupt with intention, academic norms. Consider how honesty helps you to re-pattern your ways of being, knowing, and doing. Attend carefully to how you are connected to place, how you are in relation to others, and how you nourish your soul. Know what you care about, why you care, and articulate this to others. Rather than listening in order to respond, listen with openness and generosity; listen to be changed. Hold imperfections gently, without condescending judgment. It is here that subtle shifts occur. In this rich, humble space of unknowing, the courage to change can be found and we become more able to usefully address the depths of our genuine needs. 


\section{References}

Altman, K. (2012). All my relations: A 5rhythms workshop. Offered at the White Eagle Hall in Victoria, BC, September 21-23.

Archibald, J.-A. (2008). Indigenous storywork: Educating the heart, mind, body, and spirit. Vancouver, BC: UBC Press.

Battiste, M. (2009). Nourishing the learning spirit: Living our way to new thinking. Canadian Educational Association, 50(1).

Battiste, M., \& Henderson, J. S. (2009). Naturalizing Indigenous knowledge in Eurocentric education. Canadian Journal of Native Education, 32(1), 5-18.

Buechner, F. (1993). Wishful thinking: A seeker's ABC. New York, NY: HarperOne

Cajete, G. (1994). Look to the mountain: An ecology of Indigenous education. Durango, CO: Kivaki Press.

Cajete, G. (2009, April 17). Building healthy and sustainable Indigenous communities through research. Paper presented at the American Educational Research Association Conference, San Diego, CA.

Chambers, C. (2004). Research that matters: Finding a path with heart. Journal of the Canadian Association for Curriculum Studies, 2(1), 1-19.

Chambers, C. (2008). Where are we? Finding common ground in a curriculum of place. Journal of the Canadian Association for Curriculum Studies, 6(2), 113-128.

Henderson, J. G. (1992). Reflective teaching: Becoming an inquiring educator. New York, NY: Macmillan Publishing Company.

Henhawk, D. A. (2013). My critical awakening. International Review of Qualitative Research, 6(4), 510-525.

Humble. (n.d.) Oxford English Dictionary Online (2015). Retrieved from http://www.oed.com.ezproxy.library.uvic.ca

Iseke, J. (2013). Indigenous storytelling as research. International Review of Qualitative Research, 6(4), 559-577.

Kovach, M., Carriere, J., Barrett, M. J., Montgomery, H., \& Gillies, C. (2013). Stories of diverse identity locations in Indigenous research. International Review of Qualitative Research, 6(4), 487-509.

Kumashiro, K. K. (2008). Partial movements toward teacher quality... and their potential for advancing social justice. In M. Cochran-Smith, M., S. Feiman-Nemser, D. J. McIntyre, \& K. E. Demers (Eds.), Handbook of research on teacher education: Enduring questions in changing contexts, (3rd ed., pp. 238-242). New York, NY: Routledge.

Lewis, P. J., Montgomery, M., Campbell, C. A., Ritenburg, H., \& Diversi, M. (2013). Initiating a new story. International Review of Qualitative Research, 6(4), 478- 
486.

Mani, L. (2009). Sacred/Secular: Contemplative cultural critique. New Delhi, India: Routledge.

McIntosh, P. (1990). White privilege: Unpacking the invisible knapsack. Independent School, Winter, 31-36.

Meyer, M. A. (2003). Hawaiian hermeneutics and the triangulation of meaning: Gross, subtle, causal. Canadian Journal of Native Education, 27(2), 249-255.

Meyer, M. A. (2008). Indigenous and authentic: Hawaiian epistemology and the triangulation of meaning. In N. K. Denzin, Y.S. Lincoln, \& L.T. Smith (Eds.), Handbook of critical and Indigenous methodologies (pp. 217-232). Thousand Oaks, CA: Sage.

Palmer, P. J. (1998). The courage to teach: Exploring the inner landscape of a teacher's life. San Francisco, CA: Jossey-Bass.

Restoule, J., Archibald, J., Lester-Smith, D., Parent, A., \& Smillie, C. (2010). Editorial: Connecting to spirit in Indigenous research. Canadian Journal of Native Education, 33(1), 1-8.

Sanford, K., Williams, L., Hopper, T., \& McGregor, C. (2012). Indigenous principles decolonizing teacher education: What we have learned, in education, 18(2), 1834.

Smith, L. T. (2012). Decolonizing methodologies: Research and Indigenous peoples (2nd ed.). Dunedin, NZ: University of Otago Press.

Stanger, N. R. G., Tanaka, M., Tse, V. \& Starr, L., (2013). Winter counts as transformative inquiry: The role of creative imagery as an interpretation of adaptive change. Complicity: An International Journal of Complexity and Education, 10(1/2), 87-110.

Stein, J. G. (2002). The cult of efficiency. Toronto, ON: Anasazi Press.

Tanaka, M. T. (forthcoming). Learning and teaching together: Weaving Indigenous ways of knowing into education. Vancouver, BC: UBC Press.

Tanaka, M. T. (2014). Transformative Inquiry in teacher education: Evoking the soul of what matters. Teacher Development, 19(2), 133-150. doi: 10.1080/13664530.2014.992459

Tanaka, M. T., Nicholson, D., \& Farish, M. (2012). Committed to Transformative Inquiry: Three teacher educators' entry points into the mentoring role. Journal of Transformative Education, 10(4), 257-274.

Tanaka, M. T., \& Tse, V. (2015). Touching the inexplicable: Transformative Inquiry and poetry. Journal of Curriculum Theorizing, 30(3), 87-110.

Tanaka, M. T., Tse, V., Farish, M., Doll, J., Nicholson, D., \& Archer, E. (2014). Carried 
along in the tide of another's knowing: The vulnerability of mentor mentee relationships in Transformative Inquiry. Journal of Transformative Education, 12(3), 206-225. doi: 10.1177/1541344614545129

Tanaka, M., Williams, L., Benoit, Y., Duggan, R., Moir, L., \& Scarrow, J. (2007). Transforming pedagogies: Pre-service reflections on learning and teaching in an Indigenous world. Teacher Development, 11(1), 99-109.

Thayer-Bacon, B. J. (2003). Relational “(e)pistemologies.” New York, NY: Peter Lang Publishing.

Tuck, E., \& Yang, K. W. (2012). Decolonization is not a metaphor. Decolonization: Indigeneity, Education \& Society, 1(1), 1-40.

Williams, L., \& Tanaka, M. (2007). Schalay’nung Sxwey’ga: Emerging cross cultural pedagogy in the academy. Educational Insights, 8(3). Available at http://www.ccfi.educ. ubc.ca/publication/insights/v11n03/articles/williams.html.

Wilson, S. (2007). What is an indigenist research paradigm? Canadian Journal of Native Education, 30(2), 193-195.

Wilson, S. (2008). Research is ceremony. Halifax, NS: Fernwood.

\section{Endnote}

${ }^{1}$ I use lowercase "indigenous" to describe people and ways of being that are of the earth. I use capitalized "Indigenous" to indicate the political or racialized use of the term. When quoting others I am consistent with the original usage. 